Journal of Anatolian Environmental and Animal Sciences

(Anadolu Çevre ve Hayvancıllk Bilimleri Dergisi)

DOI: https://doi.org/10.35229/jaes.669773
AÇEH

Y1l: 5, Say1: 1, 2020 (61-65)

\title{
Effects of Macerate Oil of Garlic (Allium sativum, Limne), Tunceli Garlic (Allium tuncelianum, Kollman) and Oninon (Allium cepa, Limne) on Antioxidant Enzyme Activities of Rainbow Trout (Oncorhynchus mykiss L.)
}

\author{
Başar ALTINTERIM* Önder AKSU \\ Malatya Turgut Öazl University, Fisheries Faculty, Malatya, Türkiye
}

How to cite: Altınterim, B. \& Aksu, Ö. (2020). Effects of macerate oil of garlic (Allium sativum, Limne), Tunceli garlic (Allium tuncelianum, Kollman) and oninon (Allium cepa, Limne) on antioxidant enzyme activities of rainbow trout (Oncorhynchus mykiss L.). J. Anatolian Env. and Anim. Sciences, 5(1), 61-65. Atıf yapmak için: Altınterim, B. \& Aksu, Ö. (2020). Sarımsak (Allium sativum, Limne, Tunceli Sarımsağı (Allium tuncelianum, Kollman) ve Soğan (Allium cepa, Limne) Masere Yağının, Gökkuşağı Alabalığı (Oncorhynchus mykiss L.)'nın Antioksidan Enzim Aktiviteleri Üzerine Etkileri. Anadolu Çev. ve Hay. Dergisi, 5(1), 61-65.

: https://orcid.org/0000-0001-6913-6326 (iD) : https://orcid.org/0000-0003-3735-6732

*Corresponding author's: Başar ALTINTERIM

Malatya Turgut Öazl University, Fisheries

Faculty, Malatya, Türkiye.

$\triangle$ : basaraltinterim@gmail.com

Mobile telephone : +90 (506) 5114147

Abstract: In this study, antioxidant enzyme activities effects of dietary supplementation of garlic (Allium sativum, Limne) oil macerate, Tunceli garlic (Allium tuncelianum, Kollman) oil macerate and onion (Allium cepa, Limne) oil macerate on antioxidant activities [catalase (CAT), glutathione reductase (GR), glutathione peroxidase (GPx) and malondialdehyde (MDA)] in sera of rainbow trout (Oncorhynchus mykiss L.) were assessed. For this aim, rainbow trout were fed with diets containing garlic oil macerate, Tunceli garlic oil macerate, and onion oil macerate at concentration of $10 \mathrm{~g} \mathrm{~kg}^{-1}$ for 21 days. The highest CAT, GR and MDA activities were observed in onion oil macerate group, and the highest GPx activity was determined in garlic oil macerate group. GPx levels of three experimental groups were observed higher than control group. This study reported the effects of oil macerate on sera antioxidant capacities in rainbow trout (Oncorhynchus mykiss). It was found that GPx activity of garlic oil macerate group and CAT, GR, and MDA activities of onion group in sera were significantly increased.

Keywords: Allium species, dietary supplements, enzyme activity, macerated oils, oxidative stress biomarkers, rainbow rout.

\section{Sarımsak (Allium sativum, Limne, Tunceli Sarımsağı (Allium tuncelianum, Kollman) ve Soğan (Allium cepa, Limne) Masere Yağının, Gökkuşağı Alabalığı (Oncorhynchus mykiss L.)'nın Antioksidan Enzim Aktiviteleri Üzerine Etkileri}

*Sorumlu yazar: Başar ALTINTERIM

Malatya Turgut Öazl University, Fisheries Faculty, Malatya, Türkiye.

$\bigotimes$ : basaraltinterim@gmail.com

Mobile telephone : $+90(506) 5114147$
Öz: Bu çalışmada, sarımsak (Allium sativum, Limne) masere yağı, Tunceli sarımsak (Allium tuncelianum, Kollman) masere yağı ve soğan (Allium cepa, Limne) masere yağının diyet takviyesinin, gökkuşağı alabalığı (Oncorhynchus mykiss L.)'nın serumundaki katalaz (CAT), glutatyon redüktaz (GR), glutatyon peroksidaz (GPx) ve malondialdehit (MDA) gibi antioksidan aktiviteleri üzerindeki etkileri araştırılmıştır. Bu çalışmada üç masera yağın gökkuşağı alabalığı üzerindeki etkilerinin araştırılması amaçlanmıştır. Bu amaçla, gökkuşağı alabalığı, masere sarımsak yağı, masere Tunceli sarımsak yağı ve masere soğan yağı içeren diyetlerle 21 gün $10 \mathrm{~g}$ $\mathrm{kg}^{-1}$ 'de beslendi. En yüksek CAT, GR ve MDA aktiviteleri soğan yağı maserasyon grubunda gözlendi ve en yüksek GPx aktivitesi sarımsak yağı maserasyon grubunda saptanmıştır. Üç deney grubunun GPx düzeyleri kontrol grubundan daha yüksek olduğu gözlendi. Bu çalışmada, masere yağların, gökkuşağı alabalığı (Oncorhynchus mykiss)'nın serum antioksidan kapasitelerindeki etkileri bildirilmiştir. Sarımsak yağı maserasyon grubunun GPx aktivitesinin ve serumdaki soğan grubunun CAT, GR ve MDA aktivitelerinin önemli ölçüde arttığı bulunmuştur.

Anahtar kelimeler: Allium türleri, diyet takviyeleri, enzim aktivitesi, gökkuşağ1 alabalığg, masere yağlar, oksidatif stres biyobelirteçleri. 


\section{INTRODUCTION}

Fish antioxidant capacities provide information about their health status (Sinha et al., 2014). Free radicals are named as reactive oxygen species (ROS). ROS have a good indicator of physiological functions (Halliwell \& Gutteridge, 2007). The ROS is very significant indicator that determined the changes of physiological and biochemistry metabolism in fish in oxidative stress (Dziewulska et al., 2008). Fish antioxidant systems consist of enzymatic and non-enzymatic antioxidant defenses (Martínez-Tomé et al., 2001). Catalase (CAT), glutathione reductase (GR), selenium dependent glutathione peroxidase (GPx), and malondialdehyde (MDA) are natural enzymatic antioxidants. Plants are natural sources of bioactive substances and very useful in aquaculture, and they have antioxidant components (Lee et al., 2014; Vahedi et al., 2015).

Garlic (Allium sativum) belongs to Liliaceae family. Garlic contains many vitamins, allicin, ajoene, S-allyl cysteine, diallyl disulfide, S-methyl cysteine sulfoxide, and S-allyl cysteine organosulfur compounds (Dra gan et al., 2008). The active component of garlic is allicin (thio-2propene-1-sulfinic acid S-allyl ester). After the crushing of garlic. It showed up by the interaction of alliin (Rabinkov et al., 1998). Garlic has several benefits, such as antimicrobial (Kumar \& Berwal, 1998) and antioxidants (Metwally, 2009). Garlic is effective in controlling pathogens, bacteria, and fungi. It also increases the health of fish (Corzo-Martı'nez et al., 2007). Garlic was studied in different forms, such as extracts, aqueous, ethanol, and dried powder (Shin and Kim, 2004). Antioxidant properties of allicin can be attributed to its ability to neutralize hydroxyl radicals and preventing lipid peroxidation (Prasad et al., 1995).

Onion (Allium cepa) belongs to the same family (Liliaceae), which contains fat, sugar, and vitamins A, C, and B complex and includes magnesium, potassium and copper, flavonoids, and sulfur compounds (Breu, 1996). Onion is used as an antibacterial and antioxidant agent (Ramos et al., 2006). Onion and garlic are rich sources of selenium (Matek et al., 2000).

In this study, it was aimed to some antioxidant enzyme activities (CAT, MDA GPx and GR) of rainbow trout (Oncorhynchus mykiss L., 1758) by adding $1 \%$ of garlic (Allium sativum, Limne) oil macerate, Tunceli garlic (Allium tuncelianum, Kollman) oil macerate and onion (Allium cepa, Limne) oil macerate.

\section{MATERIAL AND METHOD}

This study carried out in the fisheries faculty of Malatya Turgut Özal University on November 2018-March 2019. Macerated garlic, macerated Tunceli garlic and macerated onion oil products were prepared of mixtures of whole garlic cloves and onions ground into vegetable oil was stored in sunflower oil (1/10) for 15 days to obtain oil macerate, and these oils were added to commercial trout feed at $\% 2$ ratio.

In the study, 30 rainbow trout with an average weight of $56.21 \pm 2.15 \mathrm{~g}$ was used. During the whole study, fish were fed twice a day for 21 days in the morning and the evening. Feeding was applied to an average of $2 \%$ of the live weight of fish. The feed conversion rate was determined at the end of the study.

Blood collection was performed without feeding on the fish, and the fish were anesthetized with the anesthetic agent [Benzocaine (ethyl 4-aminobenzoate 99\%, Sigma Aldrich Co, USA) $30 \mathrm{mg} / \mathrm{L}$ ] before blood collection. Trials were conducted in accordance with ethical rules (Inonu University, Faculty of Medicine, Ethics Committee of Experimental Animals and Protocol No: 2017/A-24). Blood samples were taken from the tail veins of the stunned fish and transferred to the tubes. The blood samples in tubes were waited one day at 4 "C and then centrifuged at $1000 \mathrm{~g}$ for 15 min to obtain serum.

The catalase (CAT) activity, the glutathione peroxidase (GPX) activity, the glutathione reductase (GR) activity and the malondialdehyde (MDA) activity were evaluated with CAT, GPx, GR and MDA detection kits, according to the manufacturer's instructions using CAT, GPx, GR and MDA kits (Shanghai YL Biotech Co., Ltd., China) by using DR-200Bc Microplate Reader (Shenzhen Prokan Electronics, China).

Statistical Analysis: Routine statistical methods and SPSS statistical program were used to evaluate the obtained data. Evaluation of the captured hematological data Kruskal Wallis and Mann Whitney U test were performed in $\mathrm{P}<0.05$ confidence interval.

\section{RESULTS}

Determination of enzyme activities: It was determined that parameters were statistically significant from the control group (Table 1). CAT values were statistically significant in onion group $(\mathrm{P}<0.05)$ (Figure 1$)$, GR values were statistically significant in garlic and onion groups $(\mathrm{P}<0.05)$ (Figure 2), MDA values were statistically significant in all groups $(\mathrm{P}<0.05)$ (Figure 3$)$ and $\mathrm{GPx}$ parameters of all groups were not statistically significant from the control group ( $\mathrm{P}>0.05)$ (Figure 4).

Lowercase superscripts (a, b, c, d) indicate significant differences $(\mathrm{P}<0.05)$ among different oils within each experimental diet-fed group, whereas superscripts in uppercase show significant differences $(\mathrm{P}>0.05)$ among diet groups. Each value is the mean \pm S.E. of four individual observations. Each value is the mean \pm S.E. of ten personal views. 
Table 1. Antioxidant parameters of all groups.

\begin{tabular}{lcccc}
\hline Antioxidant parameters & Control & Tunceli Garlic oil macerate & Garlic oil macerate & Onion oil macerate \\
\hline CAT & $12.25 \pm 0,75^{\text {ac }}$ & $14.52 \pm 2,05^{\text {ab }}$ & $8.23 \pm 1,08^{\mathrm{c}}$ & $17.85 \pm 4,33^{\mathrm{b}}$ \\
GR & $15.25 \pm 1,12^{\mathrm{a}}$ & $13.88 \pm 0,55^{\mathrm{ad}}$ & $8.62 \pm 0,14^{\mathrm{b}}$ & $15.32 \pm 1,52^{\mathrm{cd}}$ \\
MDA & $11.28 \pm 0,22^{\mathrm{a}}$ & $9.73 \pm 0,56^{\mathrm{bc}}$ & $8.57 \pm 0,29^{\mathrm{bd}}$ & $12.14 \pm 1,19^{\mathrm{cd}}$ \\
GPx & $11.41 \pm 0,45$ & $13.26 \pm 1,14$ & $15.03 \pm 4,61$ & $12.43 \pm 1,03$ \\
\hline CAT: catalase activity, GPX: glutathione peroxidase activity, GR: glutathione reductase activity, MDA: malondialdehyde.
\end{tabular}

Serum CAT, GR, and MDA activities of onion oil macerate were significantly higher in control group. The serum GPx activity of garlic oil macerate was the highest in all groups. GPx activity of all groups was higher than control group. GR and MDA activities in the serum were also significantly inhibited in both garlic oil macerate group and Tunceli garlic oil macerate group compared to the control group. While the CAT activity in the serum was also inhibited in garlic group, CAT activity in the serum was stimulated in Tunceli garlic group; still the highest level of CAT was determined in onion group.

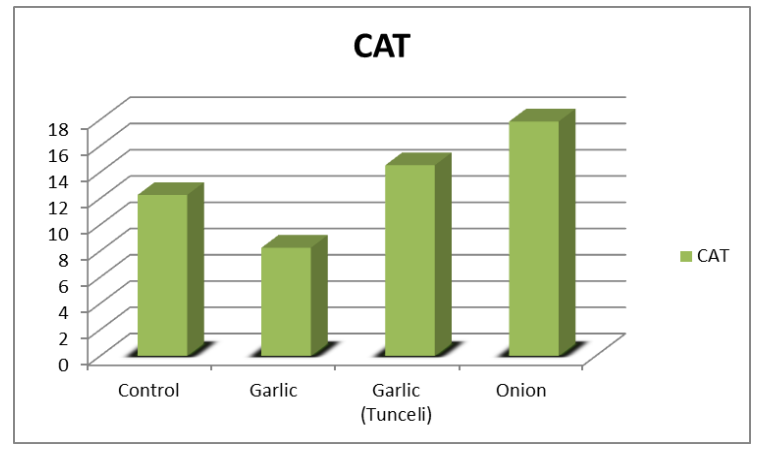

Figure 1. Activities of superoxide dismutase catalase (CAT) in trout serum.

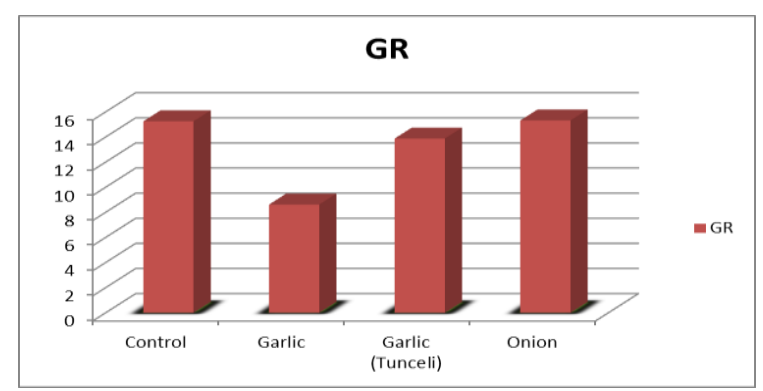

Figure 2. Activities of glutathione reductase (GR) in trout serum.

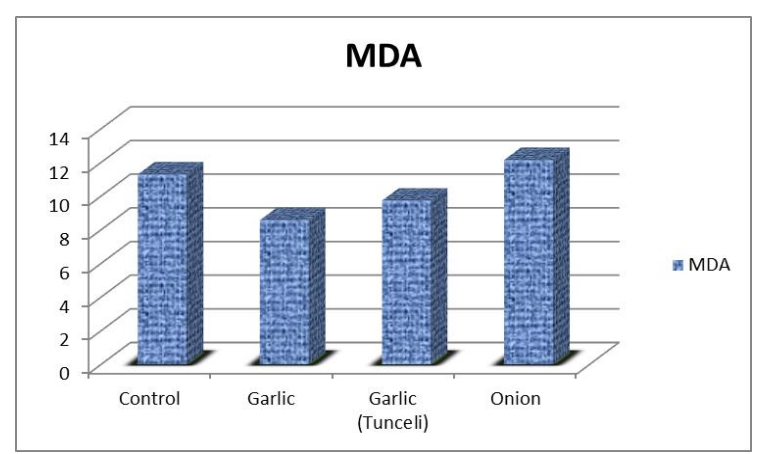

Figure 3. Activities of malondialdehyde (MDA) in trout serum.

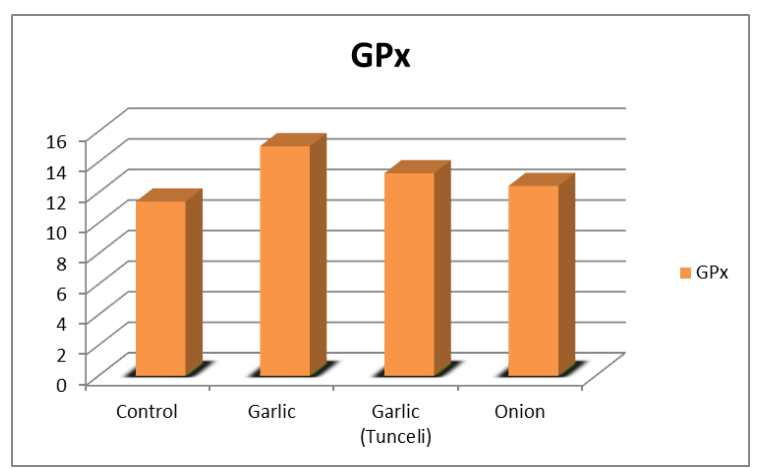

Figure 4. Activities of glutathione peroxidase (GPx) in trout serum.

\section{DISCUSSION}

ROS neutralizing activity has been connected with the enzymatic and non-enzymatic antioxidant defense systems (Jos et al., 2005). The levels in this study showed that CAT, MDA, and GR activities in the sera increased in onion group that improves the enzymatic antioxidant capacity in fish. But the action of glutathione peroxidase (GPx) of garlic oil macerate group in contrast to other businesses that were determined the highest level.

GPx levels were high in allicin species, which are a source of selenium. The highest GPx activity was detected in garlic oil macerate and afterward Tunceli garlic oil macerate and onion oil macerate compare to fish fed control diet. Similarly, results revealed that GPx enzyme activity increased in which fed with $2 \%$ garlic supplement (Nemmiche, 2017). During the production process of macerated oil, alliin is converted to allicin. The allicin in macerated oil does not have a stable structure and is rapidly decomposed into components such as dithiins, ajoene, and sulfides (Block, 1985). In another study on chicken eggs, GPx level was determined high, but CAT level was low that fed with garlic powder (Çelebi et al., 2016). Garlic oil showed stress suppression and negative feedback effect in stress groups (Altinterim and Aksu, 2019). Garlic enhanced the non-specific defense activity of fish ( $O$. niloticus) (Diab et al., 2002).

We have demonstrated that MDA increased antioxidant capacity of the sera in rainbow trout, which may especially explain the positive effects of onion oil macerate on lipid peroxidation of fish. MDA levels of garlic groups were determined lower than control group. In the same trend, MDA activity in muscle tissues of fish 
groups fed with garlic was showed a significant decrease in lipid peroxidation levels (Mahmoud et al., 2019). It occurred that onion could be occurred in respiratory burst activity of beluga (Teyssier et al., 2001). Additionally, a previous study discovered that onion powder was improved lysozyme activity of the olive flounder (Paralichthys olivaceus) juvenile (Cho \& Lee, 2012).

In summary, this study reported the effects of oil macerate on sera antioxidant capacities in rainbow trout (Oncorhynchus mykiss). The changes in sera antioxidant indices were the immunostimulatory effects of fish. Besides it was found out from different changes of GPx activity of garlic oil macerate group in sera that correlated with selenium in garlic. Glutathione peroxidase consists of four protein subunits. Each subunit contains a selenium atom (Sen \& Chakraborty, 2011).

The highest antioxidant activities (CAT, GR, and MDA) were determined onion oil macerate group. It was thought that immunostimulant effects of onion oil macerate were contained from cysteine sulfoxide (CSO) with Spropenyl-CSO as the predominant sulpur compound in onion oil. Sulphur was a component of the antioxidant enzymes (Keusgen et al., 2002; Ostrowska et al., 2004).

Although the blood values of fish fed with vegetable oil supplementation have been investigated in many studies (Altınterim et al., 2018a; 2018b; 2018c), studies on macerated oils are almost nonexistent in the literature. It is thought that these studies will be the pioneer in the studies on macerated oils.

As a result, it was found that GPx activity of garlic oil macerated group and CAT, GR, and MDA activities of onion group in sera were significantly increased. Thus, the antioxidant capacity of fish is stabilized at a high level at duration their life.

Significance Statement: There were many studies done with vegetable oils and essential oils. On the other hand, there were no studies with macerated oils. This was one of the first and pioneering works in the field of education.

\section{REFERENCES R}

Altınterim, B., Öztürk, E., Kutluyer, F. \& Aksu, Ö. (2018a). Effects of green tea (Camellia sinensis) oil on feed utilization and hematological parameters of rainbow trout (Oncorhynchus mykiss). Atatürk University Journal of Veterinary Sciences, 13(2), 159-164. DOI: 10.17094/ataunivbd.296989.

Altinterim, B., Danabas, D. \& Aksu, O. (2018b). The effects of common yarrow (Achillea millefolium Linnaeus), cinnamon (Cinnamomum zeylanicum Blume) and rosemary (Rosemarinus Officinalis Linnaeus) hydrosols on some immunological and hematological parameters of common carp
(Cyprinus carpio L., 1758). Cellular and Molecular Biology, 64(14), 19-24.

Altinterim, B., Kutluyer, F. \& Aksu, O. (2018c). Effects of Different Plant Oils Having Different Oxygen Radical Absorbance Capacity (ORAC) on Hematological Parameters of Rainbow Trout (Oncorhynchus mykiss) at High Stocking Density. Atatürk University Journal of Veterinary Sciences, 13(1), 63-69. DOI: 10.17094/ataunivbd.296703.

Altinterim, B. \& Aksu, Ö. (2019). Masere sarımsak (Allium sativum Limne) ve Tunceli sarımsag1 (Allium tuncelianum Kollman) yaglarının yogun stoklanmıs gökkusag1 alabalıklarının (Oncorhynchus mykiss W.) bazı kan parametrelerine ve NBT (Nitroblue Tetrazolium) seviyelerine etkileri. Balıkesir Üniversitesi Fen Bilimleri Enstitüsü Dergisi, 21(2), 716-723. DOI: 10.25092/baunfbed.637083.

Block, E. (1985). Chemistry of garlic and onions. Scientific American, 252, 94-99. DOI: 10.1038/scientificamerican0385-114.

Breu, W. (1996). Allium cepa L. (onion). Part 1: chemistry and analysis. Phytomedicine, 3, 293-306.

Cho, S.H. \& Lee, S.M. (2012). Onion powder in the diet of the olive flounder, Paralichthys olivaceus: effects on the growth, body composition, and lysozyme activity. Journal of the World Aquaculture Society, 43: 30-38. DOI: 10.1111/j.1749-7345.2011.00489.x.

Corzo-Martı́nez, M., Corzo, N. \& Villamiel, M. (2007). Biological properties of onions and garlic. Trends in Food Science \& Technology, 18(12), 609-625. DOI: 10.1016/j.tifs.2007.07.011.

Çelebi, Ş., Kaya, A. \& Kaya, H. (2016). Yumurta tavuğu rasyonlarına sarımsak tozu ilavesinin yumurta, kan, karaciğer, but ve gögüs dokularında bazı antioksidan enzimler üzerine etkisi. Nevşehir Bilim ve Teknoloji Dergisi TARGID Özel Sayl, 32-40. DOI: 10.17100/nevbiltek.210959.

Diab, A.S., El-Nagar, G.O. \& El-Hady, Y.M. (2002). Evaluation of Nigella sativa (black seed, Baraka), Allium sativum (garlic), and biogen as feed additives on growth performance and immunostimulants of Oreochromis niloticus fingerlings. Suez Canal Veterinary Medicine Journal, 1, 745-750.

Dra gan, S., Gergen, I. \& Socaciu, C. (2008). Functionala cu componente bioactive naturale in sindromul metabolic, Ed. Eurostampa, Timisoara, p. 200-202, 160-161, 314.

Dziewulska, K., Krzemieniecki, A. \& Domagała, J. (2008) Basic physico-chemical parameters of milt from sea trout (Salmo trutta m. trutta), brook trout (Salvelinus fontinalis) and rainbow trout (Oncorhynchus mykiss). Journal of Applied Ichthyology, 24, 497502. DOI: 10.1111/j.1439-0426.2006.00775.x.

Halliwell, B. \& Gutteridge, J. (2007). Free Radicals in Biology and Medicine, fourth ed. Oxford University Press, New York. 
Jos, Á., Pichardo, S., Prieto, A.I., Repetto, G., Vázquez, C.M., Moreno, I. \& Cameán A.M. (2005). Toxic cyanobacterial cells containing microcystins induce oxidative stress in exposed tilapia fish (Oreochromis sp.) under laboratory conditions. Aquatic Toxicology, 72, 261-71. DOI: 10.1016/j.aquatox.2005.01.003.

Keusgen, M., Schulz, H., Glodek, J., Krest, I., Kruger, H., Herchert, N. \& Keller, J. (2002). Characterization of some Allium hybrids by aroma precursors, aroma profiles, and alliinase activity. Journal of Agricultural and Food Chemistry, 50, 2884-2890. DOI: 10.1021/jf011331d.

Kumar, M. \& Berwal, J.S. (1998). Sensitivity of food pathogens to garlic (Allium sativum L.). Journal of Applied Microbiology, 84(2), 213-215. DOI: 10.1046/j.1365-2672.1998.00327.x.

Lee, D.H., Lim, S.R., Han, J.J., Lee, S.W., Ra, C.S. \& Kim, J.D. (2014). Effects of dietary garlic powder on growth, feed utilization and whole-body composition changes in fingerling sterlet sturgeon, Acipenser ruthenus. Asian-Australasian Journal of Animal Sciences, 27(9), 1303-1310. DOI: 10.5713/ajas.2014.14087.

Mahmoud, R., Aziza, A., Marghani, B. \& Eltaysh, R. (2019). Influence of Ginger and Garlic Supplementation on Growth Performance, Whole Body Composition and Oxidative Stress in the Muscles of Nile Tilapia (O. niloticus). Advances in Animal and Veterinary Sciences, 7(5), 397-404. DOI: 10.17582/journal.aavs/2019/7.5.397.404.

Martínez-Tomé, M., García-Carmona, F., Murcia, M.A. (2001). Comparison of the antioxidant and prooxidant activities of broccoli amino acids with those of common food additives. The Journal of the Science of Food and Agriculture, 81, 1019-26. DOI: $10.1002 /$ jsfa. 889 .

Matek, M., Blanusa, M. \& Grgic, J. (2000). Determination of the daily dietary selenium intake in Croatia. European Food Research and Technology, 210: 155-60. 10.1007/PL00005504.

Metwally, M.A.A. (2009). Effects of garlic (Allium sativum) on some antioxidant activities in tilapia nilotica (Oreochromis niloticus). World Journal of Fish and Marine Sciences, 1, 56-64.

Nemmiche, S. (2017). Oxidative signaling response to cadmium exposure. Toxicol Sciences, 156(1), 4-10. DOI: 10.1093/toxsci/kfw222.

Ostrowska, E., Gabler, N.K., Sterling, S.J., Tatham, B.G., Jones, R.B., Eagling, D.R., Jois, M. \& Dunshea, F.R. (2004). Consumption of brown onions (Allium cepa var. cavalier and var. destiny) moderately modulates blood lipids, hematological and hemostatic variables in healthy pigs. British Journal of Nutrition, 91, 211-218. DOI: 10.1079/BJN20031036.
Prasad, K., Laxdal, V.A., Yu, M. \& Raney, B.L. (1995). Antioxidant activity of allicin, an active principle in garlic. Molecular and Cellular Biochemistry, 148, 183-189.

Rabinkov, A., Miron, T., Konstantinovski, L., Wilchek, M., Mirelman, D. \& Weiner, L. (1998). The mode of action of allicin: trapping of radicals and interaction with thiol containing proteins. Biochimica et Biophysica Acta, 1379, 233-244. DOI: 10.1016/S0304-4165(97)00104-9.

Ramos, F.A., Takaishi, Y., Shirotori, M., Kawaguchi, Y., Tsuchiya, K., Shibata, H., Higuti, T., Tadokoro, T. \& Takeuchi, M. (2006). Antibacterial and antioxidant activities of quercetin oxidation products from yellow onion (Allium cepa) skin. Journal of Agricultural and Food Chemistry, 54, 3551-3557. DOI: 10.1021/jf060251c.

Sen, S. \& Chakraborty, R. (2011). The Role of Antioxidants in Human Health. American Chemical Society. Oxidative Stress: Diagnostics, Prevention and Therapy, Chapter 1, 1-37. DOI: 10.1021/bk-20111083.ch001.

Shin, S. H. \& M. K. Kim. (2004). Effect of dried powders or ethanol extracts of garlic flesh and peel on lipid metabolism and antithrombiogenic capacity in 16month-old rats. Journal of Nutrition and Health, 37, 515-524.

Sinha, A.K., Abd Elgawad, H., Giblen, T., Zinta, G., De Rop, M., Asard, H., Blust, R. \& De Boeck, G. (2014). Anti-oxidative defenses are modulated differentially in three freshwater teleosts in response to ammonia-induced oxidative stress. PLoS ONE, 9(4), e95319. DOI: 10.1371/journal.pone.0095319.

Teyssier, C., Amiotb, M.J., Mondyc, N., Augerc, J., Kahaned, R. \& Siessa, M.H. (2001). Effect of onion consumption by rats on hepatic drugmetabolizing enzymes. Food and Chemical Toxicology, 39, 981-98. DOI: 10.1016/S02786915(01)00056-4.

Vahedi, G., Kanno, Y., Furumoto, Y., Jiang, K., Parker, S. C., Erdos, M. R., Davis, S. R., Roychoudhuri, R., Restifo, N.P., Gadina, M. \& Tang, Z. (2015). Super-enhancers delineate disease-associated regulatory nodes in T cells. Nature, 520(7548), 558562. DOI: $10.1038 /$ nature 14154. 